\title{
AN ANALYSIS OF ILLOCUTIONARY ACTS AND IMPLICATURES IN UNDERSTANDING TOEFL SHORT CONVERSATION
}

\author{
Desi Tri Cahyaningati \\ Politeknik Perkapalan Negeri Surabaya
}

\begin{abstract}
Listening comprehension is found to be among the most difficult tasks for the learners due to several reasons. Mostly, test-takers find difficulty in interpreting the intended meaning of the utterances in the TOEFL examination. To understand the intended meaning which is implied in and beyond the utterance itself, the test takers must have background knowledge of the context of the utterances. Based on the problems faced by the test takers above, this study gives some solutions in understanding the short conversation in TOEFL so they can draw conclusion of the intended meanings. The writer uses illocutionary acts and implicatures in analyzing the problems found in TOEFL short conversation. Based on the analysis, this study concludes that TOEFL short conversations consist of four illocutionary acts classifications of five. There are Directive, Expressive, Assertive and Commisive. Most of the illocutionary acts found in TOEFL short conversations are directive, assertive and expressive. Meanwhile, Commisive is sometimes found in TOEFL short conversations. This study also gets the data of the implicatures on the utterance in TOEFL short conversations. There are some implicatures that can help the test takers in understanding the intended meaning of the utterance in TOEFL short conversations. Thus to understand the intended meaning on the utterances, the test takers can interpret the meaning by applying the illocutionary act theory and the implicatures. The illocutionary will help the test taker to identify the types of the utterance and then can understand the intended meaning of the utterance. The implicatures will explain what a speaker can imply, suggest, or mean, as different from what the speaker literally says.
\end{abstract}

Key words: illocutionary acts, implicatures, TOEFL, short conversation

The needs of mastering English especially listening skill, grammar skill and reading skill cannot be denied again. University students from any department are required to get the 450 TOEFL scores to graduate. It means that they are forced to master English skills though they are not studying English as their major in university. The data of listening scores in PPNS (Politeknik Perkapalan Negeri Surabaya) shows that their listening scores are the lowest compares to the scores of the other sections in the TOEFL test. (UPT Bahasa PPNS, 2011) 
Therefore, this study focuses on the listening section since it is the most troublesome area in the TOEFL examination especially for PPNS students test takers. Listening comprehension is found to be among the most difficult tasks for the learners due to several reasons. First, most test-takers are not familiar with the listening material produced by native speaker. Thus, the listening section is not only testing their listening but also their understanding of the spoken language which have many intended meanings.

Mostly, test-takers find difficulty in interpreting the intended meaning of the utterances in the TOEFL examination. To understand the intended meaning which is implied in and beyond the utterance itself, the test takers must have background knowledge of the context of the utterances. Sometimes, they must have special knowledge of the utterance since few numbers of listening items in TOEFL are American culturally oriented such as idiomatic expressions. If they don't understand such cultural background, the utterances will mean nothing to them.

Time limit in answering the questions after short conversations is also the major problem faced by the test takers. They have to answer the question after one short conversation in 12 seconds. It means that the test takers should decide the answer in a very short time. If they cannot decide yet, they will be disturbed by the next conversation. Mentally, to some student, it can make them get panic. Consequently, they will fail in the test. So, to overcome this problem, test takers should prepare themselves in finding the intended meaning from the short conversation in a very short time.

Based on the problems faced by the test takers above, this study will give some solutions in understanding the short conversation in TOEFL so they can draw conclusion of the intended meanings. The writer uses illocutionary acts and implicatures in analyzing the problems found in TOEFL short conversation.

Based on the background of the study, the problems are formulated as follows:

1. What are the intended meanings through speech acts and implicatures found in TOEFL short conversations? 
2. What types of illocutionary acts are found in TOEFL short conversations?

3. How are the illocutionary acts distributed in TOEFL short conversation?

\section{Illocutionary Acts}

An illocutionary act is the second dimension of speech act which is performed through communicative force of an utterance. Mostly, the speaker does not just produce well-formed utterances with no purpose. The speaker forms an utterance with some kind of function in mind. Illocutions are acts defined by social convention acts such as accosting, accusing, admitting, apologizing, challenging, complaining, condoling, congratulating, declining, deploring, giving permission, giving way, greeting, leave-taking, mocking, naming, offering, praising, promising, proposing marriage, protesting, recommending, surrendering, thanking, toasting (Hurford and Heasley, 1983: 244). This is known as the illocutionary force of the utterances.

As stated in the previous explanation about speech act classification that when people communicate, they will form an utterance with some kind of function in mind. This case can be called as the illocutionary act. The illocutionary act will be performed through the communicative force of an utterance. People in communication might form an utterance to make an offer, a request, a promise, or for some other communnicative purpose. Each utterance has different kinds of illocutionary force. Searle in Leech (1983: 105-107) divides the illocutionary acts into five-part classification as follows:

\section{Assertives}

Assertives can also be called Representatives [Searle (1977: 34-8) in Mey, (1993: 131)]. The illocutionary point of assertives is that they commit speaker to the truth of the expressed proposition. In this case, the intention of assertives is to make the words fit the world (of belief), in which a belief is expressed, and in which any proposition can occur [Searle (1977: 34-8) in Mey, (1993: 131)]. This type state what the speaker believes to be the case or not. Stating, suggesting, boasting, complaining, claiming, and reporting are examples of communicative 
forces in assertives. For instance, when the speaker asserts "John didn't love Mary”, it means that the speaker has a belief that John didn't love Mary and he expresses through the proposition "John didn't love Mary".

\section{Directives}

The illocutionary point of directives is that they produce some effects through action by the hearer. It has a world to word direction of fit, in which a wish is expressed, and in which the proposition is a future act done by the hearer [Searle (1977: 34-8) in Mey, (1993: 131)]. In this case, speaker gets someone else to do something. Directives express what the speaker wants. Ordering, commanding, requesting, advising, and recommending are examples of communicative forces in directives. For instance, when the speaker says "Why don't you spend less time watching TV?", it may mean that the speaker want the hearer not to watch TV all the time.

\section{Commissives}

The illocutionary point of commissives is that they commit the speaker (to a greater or lesser degree) to some future action. It has a world to word direction of fit, in which an intention is expressed, and in which the proposition is a future act done by the speaker [Searle (1977: 34-8) in Mey, (1993: 131)]. In this case, speaker commits himself to do something. This type express what the speaker intends. Promising, vowing, offering, are examples of communicative forces in commissives. For instance, when the speaker says "I'll never leave you", it means that the speaker commits himself not to leave the hearer.

\section{Expressives}

The illocutionary point of expressives is that they have the function of expressing, or making known, the speaker's psychological attitude towards a state of affairs which the illocution presupposes. It has no direction of fit, in which a wide range of psychological states can be expressed, and in which the proposition ascribes a property or act to the speaker or the hearer [Searle (1977: 34-8) in Mey, (1993: 131)]. This type states what the speaker feels. Thanking, congratulating, pardoning, blaming, praising, condoling, etc are examples of communicative forces in expressives. For instance, when the speaker says "Thank you so much for your generous gift!", it means that the speaker expresses his like which is 
caused by something the hearer does (in this case, the hearer gives the speaker gift).

\section{Declarations}

The illocutionary point of declaration is that they have 'successful performance' that brings about the correspondence between the propositional content and reality. It has both a word to world and a world to word direction of fit, in which no psychological state is expressed, and in which any proposition can occur [Searle (1977: 34-8) in Mey, (1993: 131)]. This type changes world through their utterances. Resigning, dismissing, christening, naming, excommunicating, appointing, sentencing, etc are examples of communicative forces in declarations. Moreover, Searle in Leech (1983: 106) states that this type is a very special category of speech act because they are performed, normally speaking, by someone who is especially authorized to do so within some institutional framework. For instance, when the speaker which is a judge produces an utterance "This court sentences you to nine years imprisonment!", then the utterance can put the person into prison. In this case, the judge has authority and power then uses it for sentencing a person by his utterance.

\section{Implicatures Theory}

The term 'implicature' is used by Grice (1975) to explain what a speaker can imply, suggest, or mean, as different from what the speaker literally says. There are conversational implicatures which are according to Grice, determined by the conventional meaning of the words used (Grice 1975 in Brown and Yule, 1983: 31).

Telling about the intended meaning, we deal with implicature. Something more than just what the words mean called implicature. It is an additional conveyed meaning (Yule, 1996: 35).

\section{Methods}

To get the data, the writer analyzed the short dialogues on Section One Listening in TOEFL tests which were taken from the ETS (English Testing 
Service) Test Preparation Kit Workbook. There are some steps which are used to analyze the problems

1. Collecting the data from the practice test

2. Analyzing the data of the Illocutionary acts

3. Analyzing the data of implicatures

4. Concluding the intended meaning

5. Specifying the types of illocutionary acts

6. Calculating the distribution of illocutionary acts

\section{Analysis}

Thus to analyze the data of the speech acts, the writer will use only the illocutionary acts aspects. There are some cases taken from the ETS (English Testing Service) Test Preparation Kit Workbook which are analyzed by the writer.

\section{Case 1 (ETS, Practice Test C)}

Woman : I'm getting really stressed out. I just don't have the time to work on all three projects.

Man : You need to set the priorities just take the time to figure out what has to be done first.

Narr : What does the man suggest the woman do?
A) Calculate how much each project will cost
B) Take time to relax
C) Discuss her stress with the project leader
D) Decide which project is most urgent

\section{a. The Data of Illocutionary act}

The above conversation consists of two classifications of speech acts.

\section{"I'm getting really stressed out. I just don't have the time to work on all}

\section{three projects."}

The woman's utterance above can be classified as expressive, 'speech acts that state what the speaker feels' (Yule, 1996:53), since they are speech acts that state what the woman feels. This implies that she has taken too many works that can make her getting stress. Her utterance may also be classified as directive, 'speech act which embody an effort on the part of the speaker to get the hearer to do something, to direct him or her toward some goal (of the speaker's mostly)' 
(Mey, 1993: 164). She performs speech acts in order to get some suggestion related to what her problem is. In this sense, her utterance is not just expressing what her feels. It is aimed at asking for suggestion. She expressed her feeling to get the advice from the hearer. She has the intended purpose that can be recognized by the man. It can be seen from the man's response.

"You need to set the priorities just take the time to figure out what has to be done first."

Man's utterance, too, can be classified as directive. Understanding what problem the man has, the man suggests that she should set her priorities. She has to decide what should be done first. He has an assumption that she is getting stress out because she can not manage her time in working her duties. That's why he suggests her to do her job based on the priority.

\section{b. The Implicature}

What is implied in this utterance, implicatures, (Mey,1993:99) may be the woman would like the man to give her some advices by expressing her feeling. She expresses her feeling that functions as a request for some suggestions or advices. Requests need acceptance or refusal. Meanwhile, man's utterance serves as direct acceptance. The man interprets the woman's expression of feeling as a request for suggestion. He assumed that maybe by prioritizing her works she would not get stressed. Therefore, the man suggests that the woman should set her priorities in working her subjects.

\section{c. The Intended Meaning}

Test takers can arrive at the correct conclusion through two ways, speech acts and implicatures. First the woman utterance functions as expressive that has communicative purpose on the listener that is asking suggestion and as the result the hearer get the intended meaning from the speaker, then directly uttering "You need to set the priorities just take the time to figure out what has to be done first". From the discussion above, test takers can come to the conclusion that what the man implies is "Decide which project is most urgent" as stated in choice (D)

\section{Case 2 (ETS, Practice Test E)}

jsh Jurnal Sosial Humaniora, Vol 5 No.1, Jun 
Man : I've had my new stereo for a whole week, but I haven't yet figured out how to record a cassette.

Woman : Didn't an instruction manual come with it?

Narr : What does the woman imply?

A) The man should take the stereo back to the store

B) The man should refer to the instruction manual

C) She'll go to the man's house and help him

D) She'll give the man her instruction manual

\section{a. The Data of Illocutionary acts}

The above conversation consists of two classifications of speech acts.

"I've had my new stereo for a whole week, but I haven't yet figured out how to record a cassette."

The man's utterance above can be classified as assertive, 'speech acts that commit speaker to the truth of the expressed proposition [Searle (1977: 34-8) in Mey, (1993: 131)]. By stating that utterance, he wants to talk about his problem in using his new stereo to record a cassette.

His utterance may also be classified as directive, 'speech act which embody an effort on the part of the speaker to get the hearer to do something, to direct him or her toward some goal (of the speaker's mostly)' (Mey, 1993: 164). He states his problem in order to get some suggestion related to what his problem is. In this sense, his utterance is not just stating his problems. It is aimed at asking for suggestion. He has the intended purpose that can be recognized by the man. It can be seen from the woman's response.

"Didn't an instruction manual come with it?"

Woman's utterance can be classified as directive. Understanding what problem the man has, the woman suggests that he should check in the instructional manual by asking. Even though the utterance is in a question, her question functions as a suggestion. She has an assumption that the man can't use his new stereo because the man didn't read the manual. She assumes that the instructional manual can help the man solve his problem. That's why she suggests him to check the instructional manual.

\section{b. The Implicatures}

jsh Jurnal Sosial Humaniora, Vol 5 No.1, Juni 
The implied meaning in this utterance maybe the man would like to state his problem in order to get some solution. It means that he is not only complaining but also hoping to get the solution. He states his problem that function as a request for some suggestion or advice. Requests need acceptance or refusal. Meanwhile, woman's utterance serves as direct acceptance. The woman interprets the man's complaining as a request for suggestion. She assumed that maybe by checking the instructional manual can solve his problems.

\section{c. The Intended Meaning}

The intended meaning of this conversation is what the woman implies. There are two ways of arriving at the intended meaning in this conversation, speech acts and implicatures. The former is that man's utterance as assertive and directive all at once. As assertive, it has a communicative purpose on the listener that is stating, while as directive, it has a communicative purpose on the listener that is getting the hearer to get some suggestions. As the result, the hearer gets the intended meaning from the speaker, then directly uttering "Didn't an instruction manual come with it?". It is used to give solutions toward his problem.

From the discussion above, test takers can come to the conclusion that what the woman implies is 'The man should refer to the instruction manual ' as stated in choice (B).

\section{Case 3 ( ETS, Practice Test D)}

Man : If you could, would you trade places with your sister?

Woman : Yeah, she's got it made.

Narr : What does the woman mean?
A) The sisters share a lot of things.
B) She and her sister will switch seats.
C) Things are going well for her sister
D) Her sister finished her cooking.

\section{a. The Data of Illocutionary acts:}

The speech act that is found in the above source of data is

"If you could, would you trade places with your sister?"

Man's utterances consist of two classifications of speech acts. The first utterance can be classified as expressive, 'speech acts that state what the speaker 
feels' (Yule, 1996: 53). In this conversation, the man expresses his compliment to the woman's sister. He asks her to be on her sister's place since he thinks that the woman's sister has better life.

This utterance may also be classified as directives, 'speech acts which embody an effort on the part of the speaker to get the hearer to do something, to direct him or her toward some goal (of the speaker's mostly)' (Mey, 1993: 164). Though the man's compliment in a question, it is used to ask justification from the hearer.

In this part, the woman also appraises her sister.

"Yeah, she's got it made"

The woman's utterance may also be classified as expressive. She states that she also agrees with the man. She admits that her sister has better life than her life. What she says implies that she would like to be on her sister's place if possible.

\section{b. The Implicatures}

What is implied in this utterance, implicatures, (Mey,1993:99) may be the man expresses his feeling in appraising the woman's sister by asking her to imagine if she is in her sister's position. Meanwhile, woman's utterance also serves as direct acceptance. She interprets the man's asking as justifying his opinion about her sister. Therefore, she also has the same opinion as the man's opinion about her sister. Recognizing the speech act of the man, later, the woman directly says a statement for justifying him by uttering "Yeah, she's got it made"

\section{c. The Intended Meanings}

There are two ways to arrive at the intended meanings, speech act and the implicatures.

The former is that man's utterance as assertive and directive all at once. As assertive, it has a communicative purpose on the listener that is complimenting, while as directive, it has a communicative purpose on the listener that is getting the hearer to get some justifications. As the result, the hearer gets the intended meaning from the speaker, then directly uttering "Yeah, she's got it made". It is used to give justification toward his opinion.From the discussion above, test takers can come to the conclusion that what the woman implies is ' Things are going well for her sister' as stated in choice (C). 


\section{Case 4 (ETS, Practice Test E)}

Woman : We need a fourth player for tennis this morning. Do you want to join us?

Man : I've got a class at nine, but Carol's free and she's really good.

Narr : What does the man suggest the man do?

a) Wait to play until after his 9 o'clock

b) Ask Carol to play tennis

c) Ask Carol if she's going to class

d) Get a tennis lesson from Carol

\section{a. The Data of Illocutionary acts:}

The speech act that is found in the above source of data is

\section{"We need a fourth player for tennis this morning. Do you want to join us?"}

Woman's utterances consist of two classifications of speech acts. The first utterance can be classified as directive, 'speech act which embody an effort on the part of the speaker to get the hearer to do something, to direct him or her toward some goal (of the speaker's mostly)' (Mey, 1993: 164). As directive, this utterance is aiming to invite someone to join her in playing tennis.

In this conversation, the man's utterance

\section{I've got a class at nine, but Carol's free and she's really good}

Man's utterance above has two types of speech acts, the first type is assertive with the function of refusing the woman's invitation. Besides having an assertive, that utterance also has a directive type functioning to give suggestion by saying that Carol can be a good partner to play tennis.

\section{b. The Implicatures}

What is implied in these utterances, implicatures, (Mey,1993:99) may be the man would like to refuse her invitation by suggesting another person to accompany her playing tennis.

\section{c. The Intended Meaning}

From the discussion above, test takers can come to the conclusion that what the woman implies is 'Ask Carol to play tennis' as stated in choice (B). In short, the intended meaning of this short conversation can be concluded from speech acts and implicatures. The former is that woman's utterance as directive. 
As directive, it has a communicative purpose on the listener that is inviting someone to play tennis with and as the result, the hearer get the intended meaning from the speaker, then directly uttering 'I've got a class at nine, but Carol's free and she's really good'. It is used to show his refusal by suggesting to ask Carol to play tennis with.

\section{Case 5 (ETS, Practice Test A)}

Man : Whoops! Did any of my coffee just spill on you?

Woman : It's hot! Is that all you have to say?

Narr : What does the woman imply?
A) She doesn't like to drink coffee.
B) She's not upset by the accident.
C) The man should apologize.
D) The man has spilled coffee on her before.

\section{a. The Data of Illocutionary acts}

The above conversation consists of three classifications of speech acts. Let's analyze one by one.

\section{"Whoops! Did any of my coffee just spill on you? "}

The man's utterance above can be classified as expressive, 'speech acts that state what the speaker feels' (Yule, 1996:53), since it is speech act that states what the man feels. This implies that he has spilled his coffee on the woman so that he feels guilty. In this sense, his utterance is not just expressing what he feels. It is aimed at feeling guilty. He expressed his feeling to get an apology from the hearer. $\mathrm{He}$ has the intended purpose that can be recognized by the woman. It can be seen from the woman's response.

\section{"It's hot! Is that all you have to say?"}

Woman's utterance above has two types of illocutionary acts, the first type is expressive with the function of blaming the man who has spilled his coffee on her. Besides having an expressive, that utterance also has a directive type functioning to ask the man to apologize to her for having spilling his coffee on her.

\section{b. The Implicatures}

What is implied in these utterances, implicatures, (Mey,1993:99) may be the woman would like to blame the man for spilling his coffee on her and asks the 
man to apology to him all at once.

\section{c. The Intended meaning}

From the discussion above, test takers can come to the conclusion that what the woman implies is 'The man should apologize' as stated in choice (C). In short, the intended meaning of this short conversation can be concluded from illocutionary acts and implicatures. The former is that man's utterance as expressive. As expressive, it has a communicative purpose on the listener that is feeling guilty and as the result, the hearer get the intended meaning from the speaker, then directly uttering "It's hot! Is that all you have to say?" to show that it is not just guilty feeling that the woman needs but more than that, that is apologizing.

\section{Case 6 (ETS, Practice Test A)}

Man : Do you have to play that music so loud? I've got a test tomorrow!

Woman : Sorry. I didn't realize you were studying

Narr : What will the woman probably do?
A) Turn down the volume
B) Help the man study for a test
C) Play a different kind of music
D) Speak Louder

\section{a. The Data of Illocutionary acts}

The above conversation consists of two classifications of illocutionary acts.

\section{" Do you have to play that music so loud? I've got a test tomorrow! "}

The man's utterance above can be classified as assertive, 'speech acts that state what the speaker believes to be the case or not' (Yule, 1996:53). This implies that he complains about the loud of music play which is played by the man. His utterance may also be classified as directive, 'speech act which embody an effort on the part of the speaker to get the hearer to do something, to direct him or her toward some goal (of the speaker's mostly)' (Mey, 1993: 164). He performs speech acts in order to get the hearer to turn down the music play. He has the intended purpose that can be recognized by the woman. It can be seen from the woman's response.

\section{"Sorry. I didn't realize you were studying "}


Woman's utterance, too, can be classified as expressive. Understanding the man's utterance that he is bothered with her music play, the woman, then, expresses her feeling by apologizing to the man.

\section{b. The Implicature}

What is implied in this utterance, implicatures, (Mey,1993:99) may be the man would like the woman to turn down the music play. He expresses his feeling that functions as a complain. Besides complaining, the man also wants the man to turn down the volume of music play. Recognizing the speech act of the man, later, the woman directly says an apology for bothering him by uttering “ Sorry. I

\section{didn't realize you were studying “.}

\section{c. The Intended meaning}

From the discussion above, test takers can come to the conclusion that what the woman implies is 'Turn down the volume' as stated in choice (A). In short, the intended meaning of this short conversation can be concluded from illocutionary acts and implicatures. The former is that man's utterance as assertive and directive all at once. As assertive, it has a communicative purpose on the listener that is complaining, while as directive, it has a communicative purpose on the listener that is getting the hearer to turn down the volume of music play. As the result, the hearer gets the intended meaning from the speaker, then directly uttering "Sorry. I didn't realize you were studying" to show that she feels sorry and may turn down the volume of the music player.

\section{Case 7 (ETS, Practice Test E)}

Woman : One of the members of the dormitory council is quitting. Do you know of anyone who'd be interested in taking her place?

Man : I'm not sure, but I'll certainly keep an eye for you.

Narr : What will the woman probably do?
A. Join the dormitory council himself
B. Attend the next council meeting
C. Persuade the other council members not to quit
D. Help the woman find someone to fill the vacancy

\section{a. The Data of Illocutionary acts}

The above conversation consists of two classifications of speech acts. 


\section{"One of the members of the dormitory council is quitting. Do you know of anyone who'd be interested in taking her place?"}

The woman's utterance above can be classified as assertive, 'speech acts that state what the speaker believes to be the case or not' (Yule, 1996:53). This implies that she is looking for someone who is interested to be a member of dormitory council.

Her utterance may also be classified as directive, 'speech act which embody an effort on the part of the speaker to get the hearer to do something, to direct him or her toward some goal (of the speaker's mostly)' (Mey, 1993: 164). She performs speech acts in order to ask suggestion from the hearer. She has the intended purpose that can be recognized by the man. It can be seen from the woman's response.

\section{"I'm not sure, but I'll certainly keep an eye for you."}

Man's utterance, too, can be classified as commissive. In this case, speaker commits himself to do something. This type express what the speaker intends. He promises to the woman to help her finding the person that she needs.

\section{b. The Implicature}

What is implied in this utterance, implicatures, (Mey,1993:99) may be the woman would like the man to give some suggestion about her problem in finding the person to be the dormitory council. Understanding the woman's utterance, the man promises to help the woman by finding the person who is interested to be the member of dormitory council.

\section{c. The Intended meaning}

From the discussion above, test takers can come to the conclusion that what the man implies is 'Help the woman find someone to fill the vacancy'as stated in choice (D). In short, the intended meaning of this short conversation can be concluded from illocutionary acts and implicatures. The former is that woman's utterance as directive which has a communicative purpose on the listener that is asking some suggestions. As the result, the hearer gets the intended meaning from the speaker, then directly uttering 'I'm not sure, but I'll certainly keep an eye for you." It is used to show that he promises to help her finding the person interested to be a member of dormitory council.

jsh Jurnal Sosial Humaniora, Vol 5 No.1, Jun 


\section{Types of Illocutionary Acts in TOEFL Short Dialogue}

After collecting and classifying the short dialogues, the writer calculated that there are six problems of speech acts that can be found in Listening section of TOEFL.

1. advice

2. refusal

3. complain

4. request

5. apology

6. compliment

7. vowing

8. offering

Those eight problems of speech acts are distributed in each set of the TOEFL test. The total number of speech acts questions and its distribution can be seen on the table 1 .

Table1. The total number of speech acts questions and its distribution

\begin{tabular}{|l|l|l|l|l|l|}
\hline Unit & A & B & C & D & E \\
\hline Speech act & 24 & 11 & 21 & 21 & 20 \\
\hline
\end{tabular}

The table shows that the number of speech act in a set of short conversation (Part A Listening) is more than a third. Thus the writer also analyzed the use of four illocutionary acts classifications of five from the ETS (English Testing Service) Test Preparation Kit Workbook. There are Directive, Expressive, Assertive and Commisive. The distribution can be seen in Table 2 .

Table 2. Speech act distribution in ETS Workbook

\begin{tabular}{|l|c|c|c|c|}
\hline & Directive & Expressive & Assertive & Commisive \\
\hline ETS,PTA & 9 & 5 & 4 & 1 \\
\hline ETS, PTB & 3 & 3 & 5 & 1 \\
\hline ETS, PTC & 5 & 9 & 5 & 1 \\
\hline
\end{tabular}




\begin{tabular}{|l|l|l|l|l|}
\hline ETS, PTD & 5 & 6 & 7 & 3 \\
\hline ETS, PTE & 6 & 4 & 7 & 3 \\
\hline
\end{tabular}

Based on the frequency of speech acts distribution in ETS workbook, it can be seen that the most frequent speech acts are directive and expressive. Meanwhile the commissive speech act is less found in that workbook.

\section{Conclusion}

Based on the analysis, this study concludes that TOEFL short conversations consist of four illocutionary acts classifications of five. There are Directive, Expressive, Assertive and Commisive. Most of the illocutionary acts found in TOEFL short conversations are Directive. Meanwhile Expressive, Assertive and Commisive are sometimes found in TOEFL short conversations.

This study also gets the data of the implicatures on the utterance in TOEFL short conversations. There are some implicatures that can help the test takers in understanding the intended meaning of the utterance in TOEFL short conversations.

Thus to understand the intended meaning on the utterances, the test takers can interpret the meaning by applying the illocutionary act theory and the implicatures. The illocutionary act theory will help the test taker to identify the types of the utterance and then can understand the intended meaning of the utterance. However, the implicatures will explain what a speaker can imply, suggest, or mean, as different from what the speaker literally says.

\section{Suggestion}

The results of this study offer some suggestions in preparing the test takers to perform the listening section on TOEFL.

1. The teacher should explain the way to understand the intended meaning by applying the illocutionary act and implicatures theories.

2. To get more understanding on the intended meaning asked in TOEFL, the test taker should understand the illocutionary acts and the implicature aspects that can be applied in analyzing the utterance. 
3. The test takers should not focus only on the second speaker since the first speaker also has function in giving the situational background

\section{References}

Brown, Gillian and George Yule. 1983.

Discourse Analysis. Cambridge:

Cambridge University Press.

Cutting, Joan. 2002. Pragmatics and Discourse: A resource book for students.

London: Routledge.

Educational Testing Service. 1995. TOEFL Preparation Kit. Princeton:

Educational Testing Service.

Graddol, David. 1980. Talk and Text. In A. K Pugh, V. J Lee and J Swann (Eds.).

Language and Language Use. London: Heinemann Educational Books

Ltd, pp.310-311.

Hurford, James R and Brendan Heasley. 1983. Semantics: A Coursebook.

Cambridge: Cambridge University Press.

Leech, Geoffrey. 1983. Principles of Pragmatics. New York: Longman Inc.

Levinson, Stephen C. 1983. Pragmatics. Cambridge: Cambridge University Press.

Lyons, John. 1977. Semantics. Cambridge: Cambridge University Press.

Searle, John R. 1969. Speech Acts: An Essay in the Philosophy of Language.

Cambridge: Cambridge University Press.

Stubbs, Michael. 1983. Discourse Analysis: The Sociolinguistic Analysis of

Natural Language. Chicago: The University of Chicago Press.

Yule, George. 1996. Pragmatics. Oxford: Oxford University Press.

jsh Jurnal Sosial Humaniora, Vol 5 No.1, Juni 
